\title{
Does Maternal Antepartum Hypothyroidism Cause Fetal and Neonatal Hyponatremia?
}

\author{
Ahmed R.G* \\ Division of Anatomy and Embryology, Zoology Department, Faculty of Science, Beni-Suef University, Beni- \\ Suef, Egypt
}

*Corresponding Author: Ahmed R.G, Division of Anatomy and Embryology, Zoology Department, Faculty of Science, Beni-Suef University, Beni-Suef, Egypt, Email: ahmedragab08@ gmail.com

\section{HYPOTHESIS FORMATION}

The activities of maternal thyroid hormones (THs) are important for the advancement of the prenatal and postnatal development (El-bakry et al., 2010; Ahmed, 2011, 2012a,b, 2013, 2014, 2015a-c, 2016a-d, 2017a-v \& 2018a-j; Ahmed et al., 2008, 2010, 2012, 2013a,b, 2014; 2015a,b\& 2018a,b; Ahmed and Ahmed, 2012; Ahmed and Incerpi, 2013; Van Hercket al., 2013; Ahmed and El-Gareib, 2014,Incerpi et al., 2014; Candelotti et al., 2015; De Vito et al., 2015; El-Ghareeb et al., 2016; Ahmed and ElGareib, 2017; Endendijk et al., 2017; Gigena et al., 2017). The homeostasis between the levels of THs (Ahmed and Incerpi, 2013) and the placental development (Valerio et al., 2015) regulates the electrolytes equilibrium between dams and their fetuses/newborns.

On the other hand, hyponatremia, electrolyte abnormality, can cause by the excess free $\mathrm{H}_{2} \mathrm{O}$ intake and the impairment in its excretion due to arginine vasopressin (AVP) excess (Agathis et al., 2015). Another probable cause of hyponatremia is hypothyroidism/myxedema (Macaron et al., 1978; Schutt-Aine et al., 1980; Chelimsky et al., 1997; Nakano et al., 2000). More importantly, possible mechanisms of hyponatremia associated with hypothyroidism can be explained as the following (Derubertis et al., 1971; Hanna and Scanlon, 1997; Kreisman and Hennessey, 1999; Adrogue and Madias, 2000; Schmitz et al., 2001; Milionis et al., 2002; Chen et al., 2005; Warner et al., 2006; Liamis et al., 2011; Schwarz et al., 2012; Filippatos and Elisaf, 2013; Hammami et al., 2013; Baajafer et al., 2014; Pantalone and Hatipoglu, 2014; Abuzaid and Birch, 2015; Filippatos et al., 2016; Liamis et al., 2017): (1) increased the syndrome of inappropriate antidiuretic hormone secretion (SIADH; increase urine $\mathrm{Na}^{+}$); (2) decreased the cardiac outputs; (3) increased the level of antidiuretic hormone (ADH); (4) saltlosing nephropathy and hypovolemia; (5) decreased the glomerular filtration rate (GFR); (6) low-iodine and solute intake; (7)decreased the water delivery to the kidney diluting segment; (8) decreased the excretion of water content; and (9) water retention. In disagreement with the above results, some investigators did not find association between the infants with congenital hypothyroidism and hyponatremia (Croal et al., 1997; Asami and Uchiyama, 2004; Katoch et al., 2013; Berndt et al., 2015). On the other hand, Liamis et al. (2017) reported that several causes of hyponatremia such as infections, drugs or adrenal insufficiency should be considered with the mild/moderate hypothyroidism.

On the above data, it can be showed that the normal passage of transplacental THs may be essential for the electrolyte equilibrium between the dams and their newborns. In addition, any disruption in the activities of maternal antepartum THs (hypothyroidism) may disturb the electrolyte equilibrium between the dams and their fetuses/neonates. My hypothesis is the maternal antepartum dyselectrolytemia may intensify the risk of pre-delivery and may cause neonatal disorders. Though, the mechanism of maternofetal dyselectrolytemia or metabolic derangement remains in determinate. Thus, I advise to treat the maternal electrolyte imbalance and thyroid functions before the gestation or correct the dyselectrolytemia and thyroid functions in the neonates after the labor. Moreover, a care postpartum for both dams and their newborns may be required to get a good outcome. 


\section{REFERENCES}

[1] Abuzaid, A.S., Birch, N., 2015. The controversies of hyponatraemia in hypo thyroidism: weighing the evidence. Sultan Qaboos University Medical Journal 15, e207-e 212.

[2] Adrogue, H.J., Madias, N.E., 2000. Hyponatremia. New England Journal of Medicine 342, 1581-1589.

[3] Agathis, N.T., Libman, I.M., Moritz, M.L., 2015. Hyponatremia due to Severe Primary Hypothyroidism in an Infant. Front. Pediatr. 3, 96.

[4] Ahmed, O.M., Abd El-Tawab, S.M., Ahmed, R.G., 2010. Effects of experimentally induced maternal hypothyroidism and hyperthyroidism on the development of rat offspring: I- The development of the thyroid hormonesneurotransmitters and adenosinergic system interactions. Int. J. Dev. Neurosci. 28, 437-454.

[5] Ahmed, O.M., Ahmed, R.G., 2012. Hypothyroidism. In A New Look At Hypothyroidism. Dr. D. Springer (Ed.), ISBN:978-953-51-0020-1), In Tech Open Access Publisher, Chapter 1, pp. 1-20.

[6] Ahmed, O.M., Ahmed, R.G., El-Gareib, A.W., El-Bakry, A.M., Abd El-Tawaba, S.M., 2012. Effects of experimentally induced maternal hypothyroidism and hyperthyroidism on the development of rat offspring: II-The developmental pattern of neurons in relation to oxidative stress and antioxidant defense system. Int. J. Dev. Neurosci. 30, 517-537.

[7] Ahmed, O.M., El-Gareib, A.W., El-bakry, A.M., Abd El-Tawab, S.M., Ahmed, R.G., 2008. Thyroid hormones states and brain development interactions. Int. J. Dev. Neurosci. 26(2), 147-209. Review.

[8] Ahmed, R.G., 2011. Perinatal 2, 3, 7, 8tetrachlorodibenzo-p-dioxin exposure alters developmental neuroendocrine system. Food Chem. Toxicology, 49, 1276-1284.

[9] Ahmed, R.G., 2012a. Maternal-newborn thyroid dysfunction. In the Developmental Neuro endocrinology, pp. 1-369. Ed R.G. Ahmed. Germany: LAP LAMBERT Academic Publishing GmbH \& Co KG.

[10] Ahmed, R.G., 2012b. Maternal-fetal thyroid interactions, Thyroid Hormone, Dr. N.K. Agrawal (Ed.), ISBN: 978-953-51-0678-4, In Tech Open Access Publisher, Chapter 5, pp. 125-156.

[11] Ahmed, R.G., 2013. Early weaning PCB 95 exposure alters the neonatal endocrine system: thyroid adipokine dysfunction. J. Endocrinol. 219 (3), 205-215.

[12] Ahmed, R.G., 2014. Editorial: Do PCBs modify the thyroid-adipokine axis during development? Annals Thyroid Res. 1(1), 11-12.
[13] Ahmed, R.G., 2015a. Chapter 1: Hypothyroidism and brain development. In advances in hypothyroidism treatment. Avid Science Borsigstr. 9, 10115 Berlin, Berlin, Germany. Avid Science Publications level 6, Melange Towers, Wing a, Hitec City, Hyderabad, Telangana, India. pp. 1-40.

[14] Ahmed, R.G., 2015b. Hypothyroidism and brain developmental players. Thyroid Research J. 8(2), 1-12.

[15] Ahmed, R.G., 2015c. Editorials and Commentary: Maternofetal thyroid action and brain development. J. of Advances in Biology; 7(1), 1207-1213.

[16] Ahmed, R.G., 2015d. Developmental adipokines and maternal obesity interactions. J. of Advances in Biology; 7(1), 1189-1206.

[17] Ahmed, R.G., 2016a. Maternal bisphenol A alters fetal endocrine system: Thyroid adipokine dysfunction. Food Chem. Toxicology, 95, 168-174.

[18] Ahmed, R.G., 2016b. Gestational dexamethasone alters fetal neuroendocrine axis. Toxicology Letters, 258, 46-54.

[19] Ahmed, R.G., 2016c. Maternal iodine deficiency and brain disorders. Endocrinol. Metab. Syndr. 5, 223. http://dx.doi.org/ 10.4172 /2161-1017.1000223.

[20] Ahmed, R.G., 2016d. Neonatal polychlorinated biphenyls-induced endocrine dysfunction. Ann. Thyroid. Res. 2 (1), 34-35.

[21] Ahmed, R.G., 2017a. Developmental thyroid diseases and GABAergic dysfunction. EC Neurology 8.1, 02-04.

[22] Ahmed, R.G., 2017b. Hyperthyroidism and developmental dysfunction. Arch Med. 9, 4.

[23] Ahmed, R.G., 2017c. Anti-thyroid drugs may be at higher risk for perinatal thyroid disease. EC Pharmacology and Toxicology 4.4, 140-142.

[24] Ahmed, R.G., 2017d. Perinatal hypothyroidism and cytoskeleton dysfunction. Endocrinol Metab Syndr 6, 271. doi:10.4172/2161-1017. 1000271

[25] Ahmed, R.G., 2017e. Developmental thyroid diseases and monoaminergic dysfunction. Advances in Applied Science Research 8(3), 01-10.

[26] Ahmed, R.G., 2017f. Hypothyroidism and brain development. J. Anim Res Nutr. 2(2), 13.

[27] Ahmed, R.G., 2017g. Antiepileptic drugs and developmental neuroendocrine dysfunction: Every why has A Wherefore. Arch Med 9(6), 2.

[28] Ahmed, R.G., 2017h. Gestational prooxidantantioxidant imbalance may be at higher risk for postpartum thyroid disease. Endocrinol Metab Syndr 6, 279. doi:10.4172/2161-1017.1000279.

[29] Ahmed, R.G., 2017i. Synergistic actions of thyroid-adipokines axis during development. Endocrinol Metab Syndr 6, 280. doi:10.4172 / 2161-1017.1000280. 
[30] Ahmed, R.G., 2017j. Thyroid-insulin dysfunction during development. International Journal of Research Studies in Zoology 3(4), 73-75. DOI: http://dx.doi.org/10.20431/2454941X.0304010.

[31] Ahmed, R.G., 2017k. Developmental thyroid diseases and cholinergic imbalance. International Journal of Research Studies in Zoology 3(4), 7072. DOI: http://dx.doi.org/10.20431/2454-941 X.0304009.

[32] Ahmed, R.G., 20171. Thyroid diseases and developmental adenosinergic imbalance. Int $\mathbf{J}$ Clin Endocrinol 1(2), 053-055.

[33] Ahmed, R.G., 2017m. Maternal anticancer drugs and fetal neuroendocrine dysfunction in experimental animals. Endocrinol Metab Syndr 6, 281. doi:10.4172/2161-1017.1000281.

[34] Ahmed, R.G., 2017n. Letter: Gestational dexamethasone may be at higher risk for thyroid disease developing peripartum. Open Journal of Biomedical \& Life Sciences (Ojbili) 3(2), 01-06.

[35] Ahmed, R.G., 2017o. Deiodinases and developmental hypothyroidism. EC Nutrition 11.5, 183-185.

[36] Ahmed, R.G., 2017p. Maternofetal thyroid hormones and risk of diabetes. Int. J. of Res. Studies in Medical and Health Sciences 2(10), 18-21.

[37] Ahmed, R.G., 2017r.Association between hypothyroidism and renal dysfunctions. International Journal of Research Studies in Medical and Health Sciences 2(11), 1-4.

[38] Ahmed, R.G., 2017s.Maternal hypothyroidism and lung dysfunction. International Journal of Research Studies in Medical and Health Sciences 2(11), 8-11.

[39] Ahmed, R.G., 2017t.Endocrine disruptors; possible mechanisms for inducing developmental disorders. International journal of basic science in medicine (IJBSM) 2(4), 157-160.

[40] Ahmed, R.G., 2017u. Maternal thyroid hormones trajectories and neonatal behavioral disorders. ARC Journal of Diabetes and Endocrinology 3(2), 18-21.

[41] Ahmed, R.G., 2017v.Maternal thyroid dysfunction and neonatal cardiac disorders. Insights Biol Med. 1, 092-096.

[42] Ahmed, R.G., 2018a. Maternal hypothyroidism and neonatal testicular dysfunction. International Journal of Research Studies in Medical and Health Sciences 3(1), 8-12.

[43] Ahmed, R.G., 2018b. Maternal hypothyroidism and neonatal depression: Current perspective. International Journal of Research Studies in Zoology 4(1), 6-10. DOI: http://dx.doi.org/10. 20431/2454-941X.0401002.

[44] Ahmed, R.G., 2018c. Non-genomic actions of thyroid hormones during development. App
Clin Pharmacol Toxicol: ACPT-108. DOI: 10.29011/ACPT-109. 100008.

[45] Ahmed, R.G., 2018d. Maternal thyroid function and placental hemodynamics. ARC Journal of Animal and Veterinary Sciences 4(1), 9-13. DOI: http://dx.doi.org/10.20431/2455-2518.0401002.

[46] Ahmed, R.G., 2018e. Interactions between thyroid and growth factors during development. ARC Journal of Diabetes and Endocrinology 4(1), 1-4. DOI: $\quad$ http://dx.doi.org/10.20431/2455-5983. 0401001.

[47] Ahmed, R.G., 2018f. Maternal thyroid hormones and neonatal appetite. ARC Journal of Nutrition and Growth 4(1), 18-22. DOI: http://dx.doi.org/10.20431/2455-2550.0401005.

[48] Ahmed, R.G., 2018g. Genomic actions of thyroid hormones during development. ARC Journal of Diabetes and Endocrinology 4(1), 58. DOI: http://dx.doi.org/10.20431/2455-5983. 0401002.

[49] Ahmed, R.G., 2018h. Dysfunction of maternal thyroid hormones and psychiatric symptoms. American Research Journal of Endocrinology. 2(1), 1-6.

[50] Ahmed, R.G., 2018i. Is there a connection between maternal hypothyroidism and developing autism spectrum disorders? ARC Journal of Neuroscience 3(1), 5-8. DOI: http://dx.doi.org/10.20431/2456057X. 0301002.

[51] Ahmed, R.G., 2018j.Maternal thyroid dysfunctions and neonatal bone mal development. American Research Journal of Endocrinology (in press) $\mathrm{xx}-\mathrm{xxx}$.

[52] Ahmed, R.G., Abdel-Latif, M., Ahmed F., 2015b. Protective effects of GM-CSF in experimental neonatal hypothyroidism. International Immuno pharmacology 29, 538543.

[53] Ahmed, R.G., Abdel-Latif, M., Mahdi, E., ElNesr, K., 2015a. Immune stimulation improves endocrine and neural fetal outcomes in a model of maternofetal thyrotoxicosis. Int. Immuno pharmacol. 29, 714-721.

[54] Ahmed, R.G., Davis, P.J., Davis, F.B., De Vito, P., Farias, R.N., Luly, P., Pedersen, J.Z., Incerpi, S., 2013b. Nongenomic actions of thyroid hormones: from basic research to clinical applications. An update. Immunology, Endocrine \& Metabolic Agents in Medicinal Chemistry, 13(1), 46-59.

[55] Ahmed, R.G., El-Gareib, A.W. 2014. Lactating PTU exposure: I- Alters thyroid-neural axis in neonatal cerebellum. Eur. J. of Biol. and Medical Sci. Res. 2(1), 1-16.

[56] Ahmed, R.G., El-Gareib, A.W., 2017. Maternal carbamazepine alters fetal neuro endocrinecytokines axis. Toxicology 382, 59-66.

[57] Ahmed, R.G., El-Gareib, A.W., Incerpi, S., 2014. Lactating PTU exposure: II- Alters 
thyroid-axis and prooxidant-antioxidant balance in neonatal cerebellum. Int. Res. J. of Natural Sciences 2(1), 1-20.

[58] Ahmed, R.G.,El-Gareib, A.W., Shaker, H.M., 2018a.Gestational 3,3',4,4',5-pentachlorobiphenyl (PCB 126) exposure disrupts fetoplacental unit: Fetal thyroid-cytokines dysfunction. Life Sciences 192, 213-220.

[59] Ahmed, R.G.,Walaa G.H., Asmaa F.S., 2018 b. Suppressive effects of neonatal bisphenol A on the neuroendocrine system. Toxicology and Industrial Health Journal (in press) Xx-Xxx.

[60] Ahmed, R.G., Incerpi, S., 2013. Gestational doxorubicin alters fetal thyroid-brain axis. Int. J. Devl. Neuroscience 31, 96-104.

[61] Ahmed, R.G., Incerpi, S., Ahmed, F., Gaber, A., 2013a. The developmental and physiological interactions between free radicals and antioxidant: Effect of environmental pollutants. J. of Natural Sci. Res. 3(13), 74-110.

[62] Asami, T., Uchiyama, M., 2004. Sodium handling in congenitally hypothyroid neonates. ActaPaediatrica 93, 22-24.

[63] Baajafer, F.S., Hammami, M.M., Mohamed, G.E., 1999. Prevalence and severity of hyponatremia and hypercreatininemia in shortterm uncomplicated hypothyroidism. Journal of Endocrinological Investigation 22, 35-39.

[64] Berndt, M., Harbeck, B., Lindner, U., Pauli, D., Haas, C.S., 2015. Hyponatremia due to thyrotropin deficiency: a fairy tale? Mayo Clinic Proceedings 90, 1305-1307.

[65] Candelotti, E., De Vito, P., Ahmed, R.G., Luly, P., Davis, P.J., Pedersen, J.Z., Lin, H-Y., Incerpi, I., 2015. Thyroid hormones crosstalk with growth factors: Old facts and new hypotheses. Immun., Endoc. \& Metab. Agents in Med. Chem., 15, 7185 .

[66] Chelimsky, G., Davis, I.D., Kliegman, R.M., 1997. Neonatal hyponatremia associated with congenital hypothyroidism. Clin Pediatr 36(3), 177-80.

[67] Chen, Y.C., Cadnapaphornchai, M.A., Yang, J., summer, S.N., Falk, S., Li, C., Wang, W., Schrier, R.W., 2005. Nonosmotic release of vasopressin and renal aquaporins in impaired urinary dilution in hypothyroidism. American Journal of Physiology: Renal Physiology 289, F672-F678.

[68] Croal, B.L., Blake, A.M., Johnston, J., Glen, A.C., O'Reilly, D.S., 1997. Absence of relation between hyponatraemia and hypothyroidism. Lancet 350, 1402.

[69] De Vito, P., Candelotti, E., Ahmed, R.G., Luly, P., Davis, P.J., Incerpi, S., Pedersen, J.Z., 2015. Role of thyroid hormones in insulin resistance and diabetes. Immun., Endoc. \&Metab. Agents in Med. Chem., 15, 86-93.

[70] Derubertis, F.R., Michelis, M.F., Bloom, M.E., Mintz, D.H., Field, J.B., Davis, B.B., 1971.
Impaired water excretion in myxedema. American Journal of Medicine 51, 41-53.

[71] El-bakry, A.M., El-Ghareeb, A.W.,Ahmed, R.G., 2010. Comparative study of the effects of experimentally-induced hypothyroidism and hyperthyroidism in some brain regions in albino rats. Int. J. Dev. Neurosci. 28, 371-389.

[72] El-Ghareeb, A.A., El-Bakry, A.M., Ahmed, R.G., Gaber, A., 2016. Effects of zinc supplementation in neonatal hypothyroidism and cerebellar distortion induced by maternal carbimazole. Asian Journal of Applied Sciences 4(04), 1030-1040

[73] Endendijk, J.J., Wijnen, H.A.A., Pop, V.J.M., van Baar, A.L., 2017. Maternal thyroid hormone trajectories during pregnancy and child behavioral problems. Hormones \&Behav. 94, 84-92.

[74] Filippatos, T.D., Elisaf, M.S., 2013. Hyponatremia in patients with heart failure. World Journal of Cardiology 5, 317-328.

[75] Filippatos, T.D., Liamis, G., Christopoulou, F., Elisaf, M.S., 2016. Ten common pitfalls in the evaluation of patients with hyponatremia. European Journal of Internal Medicine 29, 2225.

[76] Gigena, N., Alamino, V.A., Montesinos, M.M., Nazar, M., Louzada, R.A., Wajner, S.M., Maia, A.L., Masini-Repiso, A.M., Carvalho, D.P., Cremaschi G.A., Pellizas, C.G., 2017. Dissecting thyroid hormone transport and metabolism in dendritic cells. J. Endocrinology 232, 337-350.

[77] Hammami, M.M., Almogbel, F., Hammami, S., Faifi, J., Alqahtani, A., Hashem, W., 2013. Acute severe hypothyroidism is not associated with hyponatremia even with increased water intake: a prospective study in thyroid cancer patients. BMC Endocrine Disorders 13, 27.

[78] Hanna, F.W., Scanlon, M.F., 1997. Hyponatraemia, hypothyroidism, and role of arginine-vasopressin. Lancet 350, 755-756.

[79] Incerpi, S., Hsieh, M-T., Lin, H-Y., Cheng, GY., De Vito, P., Fiore, A.M., Ahmed, R.G., Salvia, R., Candelotti, E., Leone, S., Luly, P., Pedersen, J.Z., Davis, F.B., Davis, P.J., 2014. Thyroid hormone inhibition in L6 myoblasts of IGF-I-mediated glucose uptake and proliferation: new roles for integrin $\alpha v \beta 3$. Am. J. Physiol. Cell Physiol. 307, C150-C161.

[80] Katoch, C.D., Brar, K.S., Singh, B., 2013. Evaluation of thyroid and adrenal functions in patients with hyponatremia. Medical Journal Armed Forces India 69, 237-240.

[81] Kreisman, S.H., Hennessey, J.V., 1999. Consistent reversible elevations of serum creatinine levels in severe hypothyroidism. Archives of Internal Medicine 159, 79-82.

[82] Liamis, G., Filippatos, T.D., Liontos, A., Elisaf, M.S., 2017. Hypothyroidism- associated 
hyponatremia : mechanisms, implications and treatment. European Journal of Endocrinology 176, R15-R20.

[83] Liamis, G., Milionis, H.J., Elisaf, M., 2011. Endocrine disorders: causes of hyponatremia not to neglect. Annals of Medicine 43, 179187.

[84] Macaron, C., Famuyiwa, O., 1978. Hyponatremia of hypothyroidism. Appropriate suppression of antidiuretic hormone levels. Arch Intern Med 138(5), 820-822.

[85] Milionis, H.J., Liamis, G.L., Elisaf, M.S., 2002. The hyponatremic patient: a systematic approach to laboratory diagnosis. Canadian Medical Association Journal 166, 1056-1062.

[86] Nakano, M., Higa, M., Ishikawa, R., Yamazaki, T., Yamamuro, W., 2000. Hyponatremia with increased plasma antidiuretic hormone inacase of hypothyroidism. Intern Med 39(12), 1075-8.

[87] Pantalone, K.M., Hatipoglu, B.A., 2014. Hyponatremia and the thyroid: causality or association? Journal of Clinical Medicine 4, 32-36.

[88] Schmitz, P.H., de Meijer, P.H., Meinders, A.E., 2001. Hyponatremia due to hypothyroidism: a pure renal mechanism. Netherlands Journal of Medicine 58, 143-149.
[89] Schutt-Aine, J.C., 1980. Hypothyroid myxedema and hyponatremia in an eight-yearold child: a case report. J Natl Med Assoc 72(7), 705-8.

[90] Schwarz, C., Leichtle, A.B., Arampatzis, S., Fiedler, G.M., Zimmermann, H., Exadaktylos, A.K., Lindner, G., 2012. Thyroid function and serum electrolytes: does an association really exist? Swiss Medical Weekly 142, w13669.

[91] Valerio, E., Fantinato, M., Giovannini, I.A.B., Baraldi, E., Chiandetti, L., 2015. Severe asymptomatic maternal antepartum hyponatremia leading to neonatal seizures: prevention is better than cure. Maternal Health, Neonatology, and Perinatology (2015) 1, 25.

[92] Van Herck, S.L.J., Geysens, S., Bald, E., Chwatko, G., Delezie, E., Dianati, E., Ahmed, R.G., Darras, V.M., 2013. Maternal transfer of methimazole and effects on thyroid hormone availability in embryonic tissues. Endocrinol. 218, 105-115.

[93] Warner, M.H., Holding, S., Kilpatrick, E.S., 2006. The effect of newly diagnosed hypothyroidism on serum sodium concentrations: a retrospective study. Clinical Endocrinology 64, 598-599.

Citation: Ahmed R.G. Does Maternal Antepartum Hypothyroidism Cause Fetal and Neonatal Hyponatremia?. ARC Journal of Diabetes and Endocrinology. 2018; 4(1):17-21. doi:dx.doi.org/10.20431/24555983.0401005 .

Copyright: (C) 2018 Authors. This is an open-access article distributed under the terms of the Creative Commons Attribution License, which permits unrestricted use, distribution, and reproduction in any medium, provided the original author and source are credited. 